\title{
Indoor air quality and health in schools*
}

\author{
Qualidade do ar interno e saúde em escolas
}

\author{
Ana Maria da Conceição Ferreira, Massano Cardoso
}

\begin{abstract}
Objective: To determine whether indoor air quality in schools is associated with the prevalence of allergic and respiratory diseases in children. Methods: We evaluated 1,019 students at 51 elementary schools in the city of Coimbra, Portugal. We applied a questionnaire that included questions regarding the demographic, social, and behavioral characteristics of students, as well as the presence of smoking in the family. We also evaluated the indoor air quality in the schools. Results: In the indoor air of the schools evaluated, we identified mean concentrations of carbon dioxide $\left(\mathrm{CO}_{2}\right)$ above the maximum reference value, especially during the fall and winter. The $\mathrm{CO}_{2}$ concentration was sometimes as high as $1,942 \mathrm{ppm}$, implying a considerable health risk for the children. The most prevalent symptoms and respiratory diseases identified in the children were sneezing, rales, wheezing, rhinitis, and asthma. Other signs and symptoms, such as poor concentration, cough, headache, and irritation of mucous membranes, were identified. Lack of concentration was associated with $\mathrm{CO}_{2}$ concentrations above the maximum recommended level in indoor air $(p=0.002)$. There were no other significant associations. Conclusions: Most of the schools evaluated presented with reasonable air quality and thermal comfort. However, the concentrations of various pollutants, especially $\mathrm{CO}_{2}$, suggest the need for corrective interventions, such as reducing air pollutant sources and improving ventilation. There was a statistically significant association between lack of concentration in the children and exposure to high levels of $\mathrm{CO}_{2}$. The overall low level of pollution in the city of Coimbra might explain the lack of other significant associations.
\end{abstract}

Keywords: Air pollution, indoor; Child welfare; Signs and symptoms, respiratory.

\section{Resumo}

Objetivo: Determinar se há uma associação entre a qualidade do ar interno em escolas e a prevalência de patologias alérgicas e respiratórias nas crianças que as frequentam. Métodos: Foram avaliados 1.019 alunos de 51 escolas de ensino básico na cidade de Coimbra, Portugal. A avaliação foi realizada através de um questionário com questões referentes a características demográficas, sociais e comportamentais dos alunos, assim como presença de hábitos tabágicos na família. Foi ainda avaliada a qualidade do ar interno nas escolas. Resultados: Foram identificadas concentrações médias de dióxido de carbono $\left(\mathrm{CO}_{2}\right)$ no interior das salas de aula acima da concentração máxima de referência, principalmente no período de outono/inverno, chegando a valores de $1.942 \mathrm{ppm}$, o que implica elevado risco potencial para a saúde das crianças. Os sintomas/patologias respiratórias mais prevalentes nas crianças foram crises de espirros, rinite alérgica, estertores/sibilos e asma. Outros sinais e sintomas verificados foram falta de concentração, tosse, dores de cabeça e irritação das mucosas. A falta de concentração das crianças foi associada ao ar interno das salas de aula com valores acima do máximo recomendado para $\mathrm{CO}_{2}(\mathrm{p}=0,002)$. Não houve outras associações significativas. Conclusões: A maioria das escolas estudadas apresentava razoável qualidade do ar e conforto térmico, embora a concentração de vários poluentes, sobretudo $\mathrm{CO}_{2}$, sugere a necessidade de intervenções corretivas, como redução de fontes emissoras de poluentes e melhorias da ventilação. Houve uma associação estatisticamente significativa entre a falta de concentração nas crianças e exposição a valores elevados de $\mathrm{CO}_{2}$. 0 baixo nível de poluição na cidade de Coimbra pode explicar a falta de outras associações significativas.

Descritores: Poluição do ar em ambientes fechados; Bem-estar da criança; Sinais e sintomas respiratórios.

\section{Introduction}

People spend, on average, over $80 \%$ of their time in buildings, being therefore exposed to higher concentrations of pollutants indoors

than outdoors. Children are vulnerable to such exposure, being at an increased risk of developing respiratory diseases, such as asthma. ${ }^{(1,2)}$ Asthma is

*Study carried out at the Coimbra School of Health Technology, Coimbra, Portugal.

Correspondence to: Ana Maria da Conceição Ferreira. Rua 5 de Outubro, São Martinho do Bispo, 3000, Coimbra, Portugal.

Tel. 35123 980-2430. E-mail: anaferreira@estescoimbra.pt

Financial support: None.

Submitted: 7 August 2013. Accepted, after review: 15 April 2014. 
the leading cause of hospitalization and school absenteeism, negatively affecting learning and academic performance in students in Western countries. $^{(3,4)}$

Numerous strategies can be implemented in order to reduce the risk of exposure to pollutants; good indoor air quality is indispensable and is achieved through appropriate room ventilation, as well as through ventilation and exhaust of combustion fumes and gases. Temperature control and humidity control are also indispensable. Other, practical, recommendations include daily breathing exercises and outdoor leisure activities. ${ }^{(5)}$

Given that children spend a long time in school buildings, we can predict that the conditions in such buildings affect the incidence of respiratory symptoms. ${ }^{(6,7)}$ Several studies involving children have shown a positive association between exposure to air pollutants and increased morbidity and mortality from respiratory problems. ${ }^{(8-10)}$

The objective of the present study was to determine whether indoor air quality in elementary schools in the city of Coimbra, Portugal, is associated with the prevalence of allergic and respiratory diseases in children.

\section{Methods}

The study focused on public and private elementary (1st-4th grade) schools in the Municipality of Coimbra. The schools were selected on the basis of a comparative analysis of the 81 schools and 230 classrooms (the network of public and private elementary schools) in the Municipality of Coimbra, the 2008/2015 Education Charter of the Municipality of Coimbra being taken into consideration. Various generic, demographic, and social indicators were used in the analysis. When there was only one elementary school in a given parish, that school was necessarily chosen so that all of the parishes of the Municipality of Coimbra were represented. Other aspects were taken into consideration, including school size (larger schools being selected), school surroundings, human activity, nearby traffic, and industrial activity in the area. A non-probabilistic convenience sampling procedure was used in order to select the sample. The inclusion criteria were as follows: selection of at least one school per parish; use of the aforementioned comparison criteria; and authorization from the Direção Regional de Educação do Centro (DREC, Central Regional Education Board), school clusters, and school principals. The sample consisted of 51 schools, which corresponded to 81 classrooms (35 1st-grade classrooms, 34 4th-grade classrooms, and 12 mixed classrooms). Of the total of schools, 32 were located in predominantly urban parishes, 17 were located in moderately urban parishes, and 2 were located in predominantly rural parishes. ${ }^{(11)}$

Indoor air quality was evaluated in the fall/ winter and spring/summer. In order to characterize indoor air quality, we measured temperature, relative humidity $(\mathrm{RH})$, and the concentrations of the following: carbon monoxide (CO); carbon dioxide $\left(\mathrm{CO}_{2}\right)$; ozone $\left(\mathrm{O}_{3}\right)$; nitrogen dioxide; sulfur dioxide ( $\mathrm{SO}_{2}$ ); ; volatile organic compounds (VOCs); formaldehyde; particulate matter of $2.5 \mu \mathrm{m}$ in diameter $\left(\mathrm{PM}_{2.5}\right)$; and $\mathrm{PM}$ of $10 \mu \mathrm{m}$ in diameter $\left(\mathrm{PM}_{10}\right)$. The aforementioned measurements were performed in the fall/winter (between November of 2010 and February of 2011) and in the spring/ summer (between March of 2011 and June of 2011).

According to Portuguese National technical standards NT-SCE-02, ${ }^{(12)}$ pollutants should be measured in the representative period of activity, either 2-3 $\mathrm{h}$ after the initiation of activities or after equilibrium conditions have been reached. All measurements of indoor air quality were performed during regular classes, i.e., within approximately $2 \mathrm{~h}$ after the beginning of classes (in the morning or in the afternoon), by placing the equipment in the most central position in each classroom and at the level of the airways of the students in the sitting position. All measurements were performed in accordance with Portuguese National technical standards NT-SCE-02, ${ }^{(12)}$ at 1 $\mathrm{m}$ from the floor and at least $3 \mathrm{~m}$ from the walls, between 10:30 a.m. and 5:30 p.m., for a period of $30 \mathrm{~min}$, samples for the measurement of PM, VOCs, and the remaining parameters of indoor air quality being collected every $30 \mathrm{~s}$, every 15 $\mathrm{s}$, and every $60 \mathrm{~s}$, respectively. All measurements were performed over the course of one week. On average, two measurements per day were performed in each classroom, depending on the size of the classroom.

Outdoor air quality was measured during recess, the measurements being performed at $1 \mathrm{~m}$ from the ground and at least $1 \mathrm{~m}$ from the external walls of the schools studied. ${ }^{(13)}$

For real-time measurement of air quality parameters, the following portable devices were used: VelociCalc 9555-P (TSI lnc., Shoreview, 
MN, USA), in order to measure temperature, $\mathrm{RH}$, and the concentrations of $\mathrm{CO}$ and $\mathrm{CO}_{2}$; series 500 handheld monitor (Aeroqual Ltd., Auckland, New Zealand), in order to measure the concentration of $\mathrm{O}_{3}$; QRAE (ERA Systems Europe ApS, Kastrup, Denmark), in order to measure the concentrations of nitrogen dioxide and $\mathrm{SO}_{2}$; Formaldemeter $\mathrm{htV}$ (PPM Technology, Caernarfon, UK), in order to measure formaldehyde; Voyager (Photovac Inc., Waltham, MA, USA), in order to measure the concentrations of VOCs; and DUSTTRACK (TSI Inc.), in order to measure the concentration of PM. The devices were calibrated before sampling, the "blank" (or zero) standard being used whenever necessary in order to compare the results obtained in cases of measurements performed after changing sensors. We took into consideration the conversion of the readings on the basis of the variations in temperature and pressure.

Information on the students was collected by a questionnaire that resulted from different pre-tests. Those pre-tests focused on the time it took parents or legal guardians to complete the questionnaire, as well as on their understanding of the questions depending on the topics covered. The final version covered the following topics: family characteristics (nuclear family, single-parent family, or extended family); housing characteristics (place of residence, mean length of stay, type of housing, and thermal conditions, among others); and information regarding symptoms/ diseases and physical activity levels in the children studied. Envelopes containing the questionnaires were delivered to the teachers by the principal investigator, and the teachers instructed the students to deliver the questionnaires to their parents/legal guardians.

A non-probabilistic convenience sampling procedure was used in order to select elementary school children in the 1st-4th grade. Of a total of 4,319 children, 1,019 were selected.

We measured the weight and height of the children and subsequently calculated the body mass index, by dividing the weight (in $\mathrm{kg}$ ) by height (in $\mathrm{m}^{2}$ ). Children with a body mass index above the 95th percentile were classified as overweight on the basis of the 2000 US Centers for Disease Control and Prevention percentile distribution for gender and age. ${ }^{(14)}$

The results are presented by school, and the proportions were compared by the chi-square test and Fisher's exact test. For comparison of continuous variables, ANOVA or its non-parametric equivalent (i.e., the Kruskal-Wallis test) was used. The relative risk was estimated by calculating ORs and their 95\% Cls. All statistical analyses were performed with the IBM SPSS Statistics software package, version 19.0 (IBM Corporation, Armonk, NY, USA).

In the present study, we strategically divided the schools into two categories, on the basis of $\mathrm{CO}_{2}$ levels: no health risk (i.e., mean $\mathrm{CO}_{2}$ concentrations below the maximum reference value established by Portuguese government Decree-Law no. 79/2006, i.e., $\leq 984$ ppm); and health risk (i.e., mean $\mathrm{CO}_{2}$ concentrations $>984$ ppm).

\section{Results}

The mean age of 1st-grade students was 6.20 \pm 0.42 years, and the mean age of 4 th-grade students was $9.25 \pm 0.48$ years. Most (51.63\%) of the children were male. There was a relatively uniform distribution of the 493 female children between the two grades studied. A similar trend was observed in male students.

By measuring weight and height, we found that $5 \%$ of the children included in the study were obese.

We also found that $84.6 \%$ of the children practiced sports. In 7 of the schools studied, $100 \%$ of the children practiced sports.

Regarding the level of education of the parents/ legal guardians (by area of residence, i.e., parish), of the 1,014 respondents, 436 (43\%) had finished college, and $48(4.7 \%)$ had had only 4 years of schooling. Most of the parents/legal guardians resided in predominantly urban and moderately urban parishes ( $61 \%$ and $26 \%$, respectively).

Regarding the age of the households where the children lived, we found that there were statistically significant differences: $71.3 \%$ of the households were less than 21 years of age, and $8.2 \%$ were over 40 years of age. In addition, 25.4\% of the households had mold, and there were significant differences among the households in terms of the presence of moisture and a heating system $(53.7 \%$ of the children having been found to live in households without heating systems).

The proportion of students living in households with heating and fewer signs of moisture was higher in the schools whose students had 
parents/legal guardians who had a higher level of education.

Table 1 shows the mean concentrations of indoor air quality parameters in the elementary schools in the two sampling periods, i.e., fall/ winter and spring/summer.

Mean concentrations of $\mathrm{CO}$ and $\mathrm{CO}_{2}$ were significantly higher in the fall/winter than in the spring/summer $(p<0.001)$. There was a reduction of $0.28 \mathrm{ppm}$ in the concentration of $\mathrm{CO}$ from one sampling period to another. Regarding $\mathrm{CO}_{2}$ levels, there was a reduction of $425.36 \mathrm{ppm}$ in the spring/summer. We found mean $\mathrm{CO}_{2}$ concentrations that were well above the maximum reference value (i.e., $984 \mathrm{ppm}$ ) and therefore posed health risks to the children studying in those schools.

There were significant differences between the mean formaldehyde concentration measured in the fall/winter and that measured in the spring/ summer. Mean formaldehyde concentrations were found to be significantly higher in the spring/ summer than in the fall/winter, formaldehyde levels having increased by $0.0103 \mathrm{ppm}$. Although there were no significant differences between the two sampling periods in terms of the remaining parameters, the concentrations of $\mathrm{PM}_{10}, \mathrm{O}_{3}$, VOCs, and $\mathrm{SO}_{2}$ were found to be lower in the spring/ summer than in the fall/winter. Conversely, the concentration of $\mathrm{PM}_{2.5}$ was found to be higher, although not significantly so.

In all but 2 classrooms, mean air temperatures in the fall/winter were found to be well below the reference value. In general, mean air temperatures in the spring/summer were found to be above the reference value, which was due to the external temperature and the fact that the classrooms had no cooling system.

In both sampling periods, RH values were found to be between the lower and upper limits (30-70\%). However, in the fall/winter period, 7 schools had $\mathrm{RH}$ values above $70 \%$.

Regarding the concentration of air pollutants in the outdoor air of the schools in the two sampling periods, mean concentrations of $\mathrm{CO}, \mathrm{CO}_{2}, \mathrm{PM}_{2.5}$, $\mathrm{PM}_{10}$, and formaldehyde varied significantly. CO and $\mathrm{CO}_{2}$ levels were found to be significantly lower in the fall/winter than in the spring/summer. Conversely, $\mathrm{PM}_{2.5}, \mathrm{PM}_{10}$, and formaldehyde levels were found to be significantly higher in the spring/summer than in the fall/winter.
Table 2 shows the most prevalent symptoms and diseases in the children studied.

The most prevalent symptoms/diseases in the 1st-grade children were as follows: sneezing attacks, in 24\%; lack of concentration, in 20\%; rales and wheezing, in 17\%; cough, in 16\%; and allergic rhinitis, in 16\%. In the 4th-grade children, the most prevalent symptoms/diseases were as follows: sneezing attacks, in $27 \%$; lack of concentration, in 24\%; allergic rhinitis, in $20 \%$; and cough, in $16 \%$. When we compared the children who were in the 1st grade with those who were in the 4th grade in terms of the prevalence of each symptom, we found that rales and wheezing were more common in the 1 st-grade children (having been found in 55\%), as was cough (in 51\%). The remaining symptoms/ diseases were found to be more common in the children who were in the 4 th grade.

Of all environmental parameters analyzed, $\mathrm{CO}_{2}$ levels showed the worst results, posing serious health risks. In the indoor air of the schools evaluated, mean $\mathrm{CO}_{2}$ concentrations were in general well above the maximum reference value (984 ppm), being sometimes as high as 1,942 $\mathrm{ppm}$. Given that $\mathrm{CO}_{2}$ concentrations in indoor air were found to be much higher in the fall/ winter than in the spring/summer, we sought to estimate the risk of symptoms/diseases in the elementary school children. The classrooms were classified as posing health risks or as posing no health risks on the basis of the reference value. The symptoms/diseases were reported by the parents/legal guardians through the questionnaire (Table 3).

We found no significant association between the presence/absence of asthma and exposure to classrooms with/without health risks $(p=0.831)$. However, the prevalence of asthma was $11.8 \%$ in the total population of children studied.

Chronic bronchitis occurred in 22 children $(2.2 \%)$; however, we found no significant association between the disease and exposure to high $\mathrm{CO}_{2}$ levels in the classrooms during the fall/ winter ( $p$ > 0.05). Rales/wheezing were reported in 155 children (prevalence, 15.2\%), with no significant associations ( $p>0.05$ ). Although we found no association between sneezing attacks and exposure to high $\mathrm{CO}_{2}$ levels ( $p>0.05$ ), we found that, of the 856 children studying in classrooms with high $\mathrm{CO}_{2}$ levels (health risk), $223(26.1 \%)$ had sneezing attacks. 
Table 1 - Distribution of the concentrations of pollutants in the indoor air of the 81 classrooms studied, by season. ${ }^{\mathrm{a}}$

\begin{tabular}{|c|c|c|c|c|}
\hline \multirow[t]{2}{*}{ Pollutants } & \multicolumn{2}{|c|}{ Sampling period } & \multirow{2}{*}{$\begin{array}{l}\Delta \text { fall/winter - } \\
\text { spring/summer } \\
\text { (mean) }\end{array}$} & \multirow{2}{*}{$\begin{array}{l}\text { Maximum reference } \\
\text { value according to } \\
\text { Portuguese law }\end{array}$} \\
\hline & Fall/winter & Spring/summer & & \\
\hline $\mathrm{CO}, \mathrm{ppm}$ & $0.42 \pm 0.53^{*}$ & $0.14 \pm 0.13$ & 0.28 & 10.7 \\
\hline $\mathrm{CO}_{2}, \mathrm{ppm}$ & $1578.16^{*} \pm 712.49$ & $1152.80 \pm 595.41$ & 425.36 & 984 \\
\hline $\mathrm{PM}_{2.5}, \mathrm{mg} / \mathrm{m}^{3}$ & $0.08 \pm 0.04$ & $0.10 \pm 0.03$ & -0.02 & Not mentioned \\
\hline $\mathrm{PM}_{10}, \mathrm{mg} / \mathrm{m}^{3}$ & $0.12 \pm 0.05$ & $0.11 \pm 0.03$ & 0.006 & 0.15 \\
\hline $0_{3}, \mathrm{ppm}$ & $0.002 \pm 0.060$ & $0.0009 \pm 0.0040$ & 0.001 & 0.10 \\
\hline V0Cs, ppb & $97.82 \pm 73.72$ & $90.51 \pm 65.66$ & 7.31 & 260 \\
\hline $\mathrm{SO}_{2}, \mathrm{ppm}$ & $0.005 \pm 0.020$ & $0.004 \pm 0.030$ & 0.001 & Not mentioned \\
\hline Formaldehyde, ppm & $0.01 \pm 0.01^{*}$ & $0.02 \pm 0.02$ & -0.01 & 0.08 \\
\hline
\end{tabular}

We found no association of allergic rhinitis, cough, or breathing difficulties with exposure to classrooms with or without health risks because of $\mathrm{CO}_{2}$ levels ( $\left.p>0.05\right)$; however, of the total of children controlled for each symptom, 184 $(18.9 \%)$ had rhinitis, 164 (16.1\%) had cough, and $103(10.1 \%)$ had breathing difficulties.

We sought to understand the distribution of non-respiratory symptoms by classroom with or without health risks during the fall/winter. The classification into presence or absence of health risks followed the methods described in the previous analysis (Table 4).

On the basis of the reports by the parents/legal guardians of the 1,019 children included in the present study, we calculated the prevalence of the following signs and symptoms: stress, 1.8\%; dizziness, $2.0 \%$; irritability, $4.2 \%$; headache, $8 \%$; mucosal irritation, 4.9\%; and insomnia, 4.0\%. None of the parameters evaluated were found to be significantly associated with the presence or absence of health risks in the classrooms ( $p$ $>0.05$ ). Lack of concentration was found to be associated with exposure to indoor air in which $\mathrm{CO}_{2}$ levels were $>984 \mathrm{ppm}(\mathrm{p}=0.002)$. The probability of having poor concentration was 2.143 times higher in the children who were exposed to $\mathrm{CO}_{2}$ levels $>984 \mathrm{ppm}$ than in those who were not. Of the total of children investigated in the present study, 227 (22.3\%) were found to have poor concentration.

We sought to determine whether asthma was associated with household exposure to tobacco smoke (Table 5). We found that 361 (35.43\%) of the parents/legal guardians were smokers, and, of those, $252(69.8 \%)$ had the habit of smoking in the household. Although we found no association between tobacco exposure and asthma ( $p$ > 0.05), 30 (11.9\%) of the 252 children exposed to tobacco smoke had asthma.

\section{Discussion}

Children constitute a risk group and are vulnerable to poor indoor environmental quality. The development of respiratory diseases is associated with poor air quality in school buildings. ${ }^{(6,15)}$

In the present study, the concentrations of the pollutants analyzed were in general below the maximum reference value, the exception being the concentration of $\mathrm{CO}_{2}$. However, we found significant concentrations of certain parameters, namely $\mathrm{PM}_{10}$ and VOCs.

The results of the present study showed inadequate classroom air renewal. Because of the total volume of the classrooms, the total number of classroom occupants, and the climatic conditions, classroom ventilation during breaks is insufficient to reduce $\mathrm{CO}_{2}$ levels to acceptable levels. Several recent studies, some of which were conducted in Portugal, ${ }^{(2,16,17)}$ showed high $\mathrm{CO}_{2}$ levels in schools as a result of high occupancy and inadequate ventilation. ${ }^{(18-21)}$ These results raise several questions to be answered by governments and those responsible for this area, especially after the latest restructuring carried out at the level of schools and school clusters. Large clusters increase the number of students per classroom and, consequently, reduce the number of classes, leading us to ask the following question: Won't this reduce indoor air quality and therefore have a negative impact on the health of children? 
Table 2 - Signs, symptoms, and diseases in 1st- and 4th-grade children in the city of Coimbra, Portugal.

\begin{tabular}{|c|c|c|c|c|c|c|c|c|c|}
\hline \multirow{2}{*}{\multicolumn{2}{|c|}{$\begin{array}{c}\text { Signs, symptoms, and } \\
\text { diseases }\end{array}$}} & \multicolumn{6}{|c|}{ School grade } & \multirow{2}{*}{\multicolumn{2}{|c|}{ Total }} \\
\hline & & \multicolumn{3}{|c|}{ 1st grade } & \multicolumn{3}{|c|}{ 4th grade } & & \\
\hline & & $n$ & $\%$ column & $\%$ line & $\mathrm{n}$ & $\%$ column & $\%$ line & $n$ & $\begin{array}{c}\% \\
\text { column }\end{array}$ \\
\hline \multirow[t]{3}{*}{ Asthma } & No & 451 & 89.3 & 50.2 & 448 & 87.2 & 49.8 & 899 & 88.2 \\
\hline & Yes & 54 & 10.7 & 45.0 & 66 & 12.8 & 55.0 & 120 & 11.8 \\
\hline & Total & 505 & 100.0 & 49.6 & 514 & 100.0 & 50.4 & 1.019 & 100.0 \\
\hline \multirow[t]{3}{*}{ Chronic bronchitis } & No & 495 & 98.0 & 49.6 & 502 & 97.7 & 50.4 & 997 & 97.8 \\
\hline & Yes & 10 & 2.0 & 45.5 & 12 & 2.3 & 54.5 & 22 & 2.2 \\
\hline & Total & 505 & 100.0 & 49.6 & 514 & 100.0 & 50.4 & 1.019 & 100.0 \\
\hline \multirow[t]{3}{*}{ Rales/wheezing } & No & 420 & 83.2 & 48.6 & 444 & 86.4 & 51.4 & 864 & 84.8 \\
\hline & Yes & 85 & 16.8 & 54.8 & 70 & 13.6 & 45.2 & 155 & 15.2 \\
\hline & Total & 505 & 100.0 & 49.6 & 514 & 100.0 & 50.4 & 1.019 & 100.0 \\
\hline \multirow[t]{3}{*}{ Sneezing attacks } & No & 382 & 75.6 & 50.3 & 377 & 73.3 & 49.7 & 759 & 74.5 \\
\hline & Yes & 123 & 24.4 & 47.3 & 137 & 26.7 & 52.7 & 260 & 25.5 \\
\hline & Total & 505 & 100.0 & 49.6 & 514 & 100.0 & 50.4 & 1.019 & 100.0 \\
\hline \multirow[t]{3}{*}{ Allergic rhinitis } & No & 426 & 84.4 & 51.0 & 409 & 79.6 & 49.0 & 835 & 81.9 \\
\hline & Yes & 79 & 15.6 & 42.9 & 105 & 20.4 & 57.1 & 184 & 18.1 \\
\hline & Total & 505 & 100.0 & 49.6 & 514 & 100.0 & 50.4 & 1019 & 100.0 \\
\hline \multirow[t]{3}{*}{ Breathing difficulties } & No & 459 & 90.9 & 50.1 & 457 & 88.9 & 49.9 & 916 & 89.9 \\
\hline & Yes & 46 & 9.1 & 44.7 & 57 & 11.1 & 55.3 & 103 & 10.1 \\
\hline & Total & 505 & 100.0 & 49.6 & 514 & 100.0 & 50.4 & 1.019 & 100.0 \\
\hline \multirow[t]{3}{*}{ Stress } & No & 499 & 98.8 & 49.9 & 502 & 97.7 & 50.1 & 1001 & 98.2 \\
\hline & Yes & 6 & 1.2 & 33.3 & 12 & 2.3 & 66.7 & 18 & 1.8 \\
\hline & Total & 505 & 100.0 & 49.6 & 514 & 100.0 & 50.4 & 1.019 & 100.0 \\
\hline \multirow[t]{3}{*}{ Dizziness } & No & 497 & 98.4 & 49.7 & 502 & 97.7 & 50.3 & 999 & 98.0 \\
\hline & Yes & 8 & 1.6 & 40.0 & 12 & 2.3 & 60.0 & 20 & 2.0 \\
\hline & Total & 505 & 100.0 & 49.6 & 514 & 100.0 & 50.4 & 1019 & 100.0 \\
\hline \multirow[t]{3}{*}{ Irritability } & No & 487 & 96.4 & 49.9 & 489 & 95.1 & 50.1 & 976 & 95.8 \\
\hline & Yes & 18 & 3.6 & 41.9 & 25 & 4.9 & 58.1 & 43 & 4.2 \\
\hline & Total & 505 & 100.0 & 49.6 & 514 & 100.0 & 50.4 & 1.019 & 100.0 \\
\hline \multirow[t]{3}{*}{ Headache } & No & 472 & 93.5 & 50.4 & 465 & 90.5 & 49.6 & 937 & 92.0 \\
\hline & Yes & 33 & 6.5 & 40.2 & 49 & 9.5 & 59.8 & 82 & 8.0 \\
\hline & Total & 505 & 100.0 & 49.6 & 514 & 100.0 & 50.4 & 1019 & 100.0 \\
\hline \multirow[t]{3}{*}{ Conjunctival irritation } & No & 483 & 95.6 & 49.8 & 486 & 94.6 & 50.2 & 969 & 95.1 \\
\hline & Yes & 22 & 4.4 & 44.0 & 28 & 5.4 & 56.0 & 50 & 4.9 \\
\hline & Total & 505 & 100.0 & 49.6 & 514 & 100.0 & 50.4 & 1.019 & 100.0 \\
\hline \multirow[t]{3}{*}{ Insomnia } & No & 486 & 96.2 & 49.7 & 492 & 95.7 & 50.3 & 978 & 96.0 \\
\hline & Yes & 19 & 3.8 & 46.3 & 22 & 4.3 & 53.7 & 41 & 4.0 \\
\hline & Total & 505 & 100.0 & 49.6 & 514 & 100.0 & 50.4 & 1019 & 100.0 \\
\hline \multirow[t]{3}{*}{ Cough } & No & 421 & 83.4 & 49.2 & 434 & 84.4 & 50.8 & 855 & 83.9 \\
\hline & Yes & 84 & 16.6 & 51.2 & 80 & 15.6 & 48.8 & 164 & 16.1 \\
\hline & Total & 505 & 100.0 & 49.6 & 514 & 100.0 & 50.4 & 1.019 & 100.0 \\
\hline \multirow[t]{3}{*}{ Lack of concentration } & No & 402 & 79.6 & 50.8 & 390 & 75.9 & 49.2 & 792 & 77.7 \\
\hline & Yes & 103 & 20.4 & 45.4 & 124 & 24.1 & 54.6 & 227 & 22.3 \\
\hline & Total & 505 & 100.0 & 49.6 & 514 & 100.0 & 50.4 & 1.019 & 100.0 \\
\hline
\end{tabular}

In the present study, the most prevalent reported similar results. ${ }^{(6,22,23)}$ In addition, lack symptoms/diseases were sneezing attacks, lack of concentration, allergic rhinitis, cough, rales/ of concentration was associated with $\mathrm{CO}_{2}$ levels > $984 \mathrm{ppm}$ in indoor air $(\mathrm{p}=0.002)$. The probability wheezing, and asthma. Other studies have of having poor concentration was 2.143 times 
Table 3 - Estimation of the risk of respiratory symptoms and diseases in the children who, during the fall/winter, were exposed to a mean carbon dioxide concentration that was above or below the maximum reference value.

\begin{tabular}{|c|c|c|c|c|c|c|c|c|c|c|c|c|}
\hline \multirow{3}{*}{$\begin{array}{c}\text { Respiratory } \\
\text { symptoms and } \\
\text { diseases }\end{array}$} & \multicolumn{7}{|c|}{$\begin{array}{l}\text { Maximum reference value for carbon dioxide } \\
\text { concentration }\end{array}$} & \multirow[t]{3}{*}{$c^{2}$} & \multirow[t]{3}{*}{ df } & \multirow[t]{3}{*}{$\mathrm{p}$} & \multirow[t]{3}{*}{ OR } & \multirow[t]{3}{*}{$95 \% \mathrm{Cl}$} \\
\hline & \multicolumn{3}{|c|}{ Above } & \multicolumn{2}{|c|}{ Below } & \multicolumn{2}{|c|}{ Total } & & & & & \\
\hline & $n$ & & $\%$ & $\mathrm{n}$ & $\%$ & $\mathrm{n}$ & $\%$ & & & & & \\
\hline \multirow[t]{3}{*}{ Asthma } & Yes & 100 & 11.7 & 20 & 12.3 & 120 & 11.8 & 0.046 & 1 & 0.831 & 0.946 & $0.567-1.579$ \\
\hline & No & 756 & 88.3 & 143 & 87.7 & 899 & 88.2 & & & & & \\
\hline & Total & 856 & 100.0 & 163 & 100.0 & 1019 & 100.0 & & & & & \\
\hline \multirow[t]{3}{*}{ Chronic bronchitis } & Yes & 18 & 2.1 & 4 & 2.5 & 22 & 2.2 & 0.080 & 1 & 0.777 & 0.854 & $0.285-2.556$ \\
\hline & No & 838 & 97.9 & 159 & 97.5 & 997 & 97.8 & & & & & \\
\hline & Total & 856 & 100.0 & 163 & 100.0 & 1019 & 100.0 & & & & & \\
\hline \multirow[t]{3}{*}{ Rales/wheezing } & Yes & 133 & 15.5 & 22 & 13.5 & 155 & 15.2 & 0.442 & 1 & 0.506 & 1.179 & $0.725-1.917$ \\
\hline & No & 723 & 84.5 & 141 & 86.5 & 864 & 84.8 & & & & & \\
\hline & Total & 856 & 100.0 & 163 & 100.0 & 1019 & 100.0 & & & & & \\
\hline \multirow[t]{3}{*}{ Sneezing attacks } & Yes & 223 & 26.1 & 37 & 22.7 & 260 & 25.5 & 0.810 & 1 & 0.368 & 1.200 & $0.807-1.784$ \\
\hline & No & 633 & 73.9 & 126 & 77.3 & 759 & 74.5 & & & & & \\
\hline & Total & 856 & 100.0 & 163 & 100.0 & 1019 & 100.0 & & & & & \\
\hline \multirow[t]{3}{*}{ Allergic rhinitis } & Yes & 160 & 18.7 & 24 & 14.7 & 184 & 18.1 & 1.457 & 1 & 0.227 & 1.331 & $0.835-2.122$ \\
\hline & No & 696 & 81.3 & 139 & 85.3 & 835 & 81.9 & & & & & \\
\hline & Total & 856 & 100.0 & 163 & 100.0 & 1019 & 100.0 & & & & & \\
\hline \multirow[t]{3}{*}{ Cough } & Yes & 141 & 16.5 & 23 & 14.1 & 164 & 16.1 & 0.565 & 1 & 0.452 & 1.200 & $0.745-1.933$ \\
\hline & No & 715 & 83.5 & 140 & 85.9 & 855 & 83.9 & & & & & \\
\hline & Total & 856 & 100.0 & 163 & 100.0 & 1019 & 100.0 & & & & & \\
\hline \multirow{3}{*}{$\begin{array}{l}\text { Breathing } \\
\text { difficulties }\end{array}$} & Yes & 85 & 9.9 & 18 & 11.0 & 103 & 10.1 & 0.187 & 1 & 0.666 & 0.888 & $0.518-1.522$ \\
\hline & No & 771 & 90.1 & 145 & 89.0 & 916 & 89.9 & & & & & \\
\hline & Total & 856 & 100.0 & 163 & 100.0 & 1019 & 100.0 & & & & & \\
\hline
\end{tabular}

df: degrees of freedom.

higher in the children who were exposed to $\mathrm{CO}_{2}$ levels above the reference range than in those who were not. In one study, high $\mathrm{CO}_{2}$ levels in schools were associated with rales and cough in children. ${ }^{(24)}$

Exposure to tobacco smoke in indoor environments results in an increased risk for bronchitis and asthma, among others. ${ }^{(25,26)}$ Of the 361 parents/legal guardians who were smokers, $30.2 \%$ did not smoke at home and $69.8 \%$ did. We therefore sought to determine whether there was a relationship between parents who smoked at home and symptoms/diseases in the children. We found that most of the parents/legal guardians who smoked at home had children with asthma (76.9\%), chronic bronchitis, rales/ wheezing (69.0\%), sneezing attacks (56.0\%), allergic rhinitis (65.0\%), stress (66.7\%), dizziness (85.7\%), irritability (71.4\%), headache $(75.0 \%)$, irritation of the mucous membranes of the eyes (66.7\%), dry cough (53\%), insomnia (72.7\%), breathing difficulties (70.5\%), and lack of concentration (62.2\%). The health effects of passive exposure to tobacco smoke have been the subject of numerous investigations. It is known that children are particularly susceptible, being at an increased risk of developing allergic airway disease, particularly bronchial asthma, and the diseases is more severe in children. ${ }^{(27,28)}$ Therefore-and on the basis of our results, which are worrisome from an environmental standpoint in schools-it is desirable that children be exposed to lower levels of all contaminants at home, including tobacco smoke contaminants.

Nowadays, people spend most of their time in enclosed spaces, such as school buildings. Poor indoor air quality in such buildings is associated with the development of respiratory diseases. In the present study, the most prevalent symptoms were sneezing attacks and lack of concentration.

Most of the schools studied had reasonable air quality and thermal comfort. However, the concentrations of various pollutants, especially $\mathrm{CO}_{2}$, suggest the need for corrective interventions, such as reducing air pollutant sources and improving ventilation. Several studies have shown high $\mathrm{CO}_{2}$ 
Table 4 - Estimation of the risk of non-respiratory signs and symptoms in the children who, during the fall/winter, were exposed to a mean carbon dioxide concentration that was above or below the maximum reference value.

\begin{tabular}{|c|c|c|c|c|c|c|c|c|c|c|c|c|}
\hline \multirow[t]{3}{*}{$\begin{array}{l}\text { Signs and } \\
\text { symptoms }\end{array}$} & \multicolumn{7}{|c|}{$\begin{array}{l}\text { Maximum reference value for carbon dioxide } \\
\text { concentration }\end{array}$} & \multirow[t]{3}{*}{$c^{2}$} & \multirow[t]{3}{*}{$\mathrm{df}$} & \multirow[t]{3}{*}{$\mathrm{p}$} & \multirow[t]{3}{*}{ OR } & \multirow[t]{3}{*}{$95 \% \mathrm{Cl}$} \\
\hline & \multicolumn{3}{|c|}{ Above } & \multicolumn{2}{|c|}{ Below } & \multicolumn{2}{|c|}{ Total } & & & & & \\
\hline & $r$ & 1 & $\%$ & $\mathrm{n}$ & $\%$ & $\mathrm{n}$ & $\%$ & & & & & \\
\hline \multirow[t]{3}{*}{ Stress } & Yes & 14 & 1.6 & 4 & 2.5 & 18 & 1.8 & 0.529 & 1 & 0.467 & 0.661 & $0.215-2.034$ \\
\hline & No & 842 & 98.4 & 159 & 97.5 & 1001 & 98.2 & & & & & \\
\hline & Total & 856 & 100.0 & 163 & 100.0 & 1019 & 100.0 & & & & & \\
\hline \multirow[t]{3}{*}{ Dizziness } & Yes & 17 & 2.0 & 3 & 1.8 & 20 & 2.0 & 0.015 & 1 & 0.902 & 1.081 & $0.313-3.730$ \\
\hline & No & 839 & 98.0 & 160 & 98.2 & 999 & 98.0 & & & & & \\
\hline & Total & 856 & 100.0 & 163 & 100.0 & 1019 & 100.0 & & & & & \\
\hline \multirow[t]{3}{*}{ Irritability } & Yes & 40 & 4.7 & 3 & 1.8 & 43 & 4.2 & 2.718 & 1 & 0.099 & 2.614 & $0.799-8.554$ \\
\hline & No & 816 & 95.3 & 160 & 98.2 & 976 & 95.8 & & & & & \\
\hline & Total & 856 & 100.0 & 163 & 100.0 & 1019 & 100.0 & & & & & \\
\hline \multirow[t]{3}{*}{ Headache } & Yes & 70 & 8.2 & 12 & 7.4 & 82 & 8.0 & 0.123 & 1 & 0.726 & 1.121 & $0.593-2.118$ \\
\hline & No & 786 & 91.8 & 151 & 92.6 & 937 & 92.0 & & & & & \\
\hline & Total & 856 & 100.0 & 163 & 100.0 & 1019 & 100.0 & & & & & \\
\hline \multirow[t]{3}{*}{ Mucosal irritation } & Yes & 42 & 4.9 & 8 & 4.9 & 50 & 4.9 & 0.0001 & 1 & 0.999 & 1.000 & $0.460-2.171$ \\
\hline & No & 814 & 95.1 & 155 & 95.1 & 969 & 95.1 & & & & & \\
\hline & Total & 856 & 100.0 & 163 & 100.0 & 1019 & 100.0 & & & & & \\
\hline \multirow[t]{3}{*}{ Insomnia } & Yes & 33 & 3.9 & 8 & 4.9 & 41 & 4.0 & 0.393 & 1 & 0.531 & 0.777 & $0.352-1.714$ \\
\hline & No & 823 & 96.1 & 155 & 95.1 & 978 & 96.0 & & & & & \\
\hline & Total & 856 & 100.0 & 163 & 100.0 & 1019 & 100.0 & & & & & \\
\hline \multirow{3}{*}{$\begin{array}{l}\text { Lack of } \\
\text { concentration }\end{array}$} & Yes & 206 & 24.1 & 21 & 12.9 & 227 & 22.3 & 9.888 & 1 & 0.002 & 2.143 & $1.320-3.478$ \\
\hline & No & 650 & 75.9 & 142 & 87.1 & 792 & 77.7 & & & & & \\
\hline & Total & 856 & 100.0 & 163 & 100.0 & 1019 & 100.0 & & & & & \\
\hline
\end{tabular}

df: degrees of freedom.

Table 5 - Association between asthma in children and smoking parents/legal guardians $(\mathrm{N}=361)$ smoking at home.

\begin{tabular}{|c|c|c|c|c|c|c|}
\hline \multirow{2}{*}{$\begin{array}{l}\text { Parents/legal guardians } \\
\text { smoking at home }\end{array}$} & \multicolumn{3}{|c|}{ Asthma in children } & \multirow[t]{2}{*}{$p$} & \multirow[t]{2}{*}{ OR } & \multirow[t]{2}{*}{$95 \% \mathrm{Cl}$} \\
\hline & Yes & No & TOTAL & & & \\
\hline Yes & $30(11.9)$ & $222(88.1)$ & 252 (100.0) & 0.305 & 1.502 & $0.687-3.280$ \\
\hline No & $9(8.3)$ & $100(91.7)$ & $109(100.0)$ & & & \\
\hline TOTAL & $39(10.8)$ & $322(89.2)$ & $361(100.0)$ & & & \\
\hline
\end{tabular}

levels in schools as a result of high occupancy or inadequate ventilation. ${ }^{(2,18-21)}$ We found a statistically significant association between poor concentration and exposure to high $\mathrm{CO}_{2}$ levels. One possible explanation for the lack of other significant associations is the overall low level of pollution in the city of Coimbra.

Potential limitations of the present study include the fact that the information regarding symptoms/diseases in the children was reported by their parents/legal guardians. The perception that parents/legal guardians have of their children might not correspond to reality.
The present study allowed us to assess the risks to which the population is exposed and provide guidelines for the development of measures to minimize these risks. We hope that our findings will contribute to environmental health planning in school buildings and the improvement of political strategies to promote quality of life.

\section{References}

1. Cruz H, Viegas JC. Medição experimental do escoamento do ar através de janelas abertas. ENVIRH [serial on the Internet]. Lisboa: ENVIRH. IV Conferência Nacional em Mecânica dos Fluidos, Termodinâmica e Energia, 2012 May 28-29; Lisboa. [Adobe Acrobat document, 
10p.]. Available from: http://envirh.fcm.unl.pt/images/ stories/docs/cn03.pdf

2. Viegas JC, Papoila AL, Martins P, Aelenei D, Cano M, Proença $C$, et al. Ventilação, qualidade do ar e saúde em creches e infantários resultados preliminares do Projeto ENVIRH. ENVIRH [serial on the Internet] IV Congresso Nacional Construção, 2012 Dec 18-20; Coimbra [Adobe Acrobat document, 12p.]. Available from: http://envirh. fcm.unl.pt/images/stories/docs/cn 10.pdf

3. Moonie SA, Sterling DA, Figgs L, Castro M. Asthma status and severity affects missed school days. J Sch Health. 2006;76(1):18-24. http://dx.doi. org/10.1111/j.1746-1561.2006.00062.x

4. Daisey JM, Angell WJ, Apte MG. Indoor air quality, ventilation and health symptoms in schools: an analysis of existing information. Indoor Air. 2003;13(1):53-64. http://dx.doi.org/10.1034/j.1600-0668.2003.00153.x

5. Borrego C, Neuparth N, Carvalho AC, Carvalho A, Miranda Al, Costa AM, et al. A saúde e o ar que respiramos: um caso de estudo em Portugal. Lisboa: Fundação Calouste Gulbenkian; 2008.

6. Sundell J. On the history of indoor air quality and health. Indoor Air. 2004;14 Suppl 7:51-8. http://dx.doi. org/10.1111/j.1600-0668.2004.00273.x

7. Kim JL, Elfman L, Mi Y, Johansson M, Smedje G, Norbäck D. Current asthma and respiratory symptoms among pupils in relation to dietary factors and allergens in the school environment. Indoor Air. 2005;15(3):170-82. http://dx.doi.org/10.1111/j.1600-0668.2005.00334.x

8. Braga AL, Conceição GM, Pereira LA, Kishi HS, Pereira JC, Andrade MF, et al. Air pollution and pediatric respiratory hospital admissions in São Paulo, Brazil. J Environ Med. 1999;1:95-102. http://dx.doi.org/10.1002/(SICl)10991301(199904/06) 1:2<95::AID-JEM16>3.0.C0;2-S

9. Braga AL, Saldiva PH, Pereira LA, Menezes JJ, Conceição $\mathrm{GM}$, Lin CA, et al. Health effects of air pollution exposure on children and adolescents in São Paulo, Brazil. Pediatr Pulmonol. 2001;31(2):106-13. http:// dx.doi.org/10.1002/1099-0496(200102)31:2<106::AIDPPUL1017>3.0.CO;2-M

10. Lin AC, Martins MA, Farhat SC, Pope CA 3rd, Conceição $\mathrm{GM}$, Anastácio MV, et al. Air pollution and respiratory illness of children in São Paulo, Brazil. Paediatr Perinat Epidemiol. 1999;13(4):475-88. http://dx.doi. org/10.1046/j.1365-3016.1999.00210.x

11. Portugal. Conselho Superior de Estatística. Deliberação $n^{\circ}$. 2717/2009, 28 de setembro de 2009. 8a Deliberação da Secção Permanente de Coordenação Estatística. Revisão da Tipologia de áreas urbanas. Diário da República, 2a série, Lisboa, no. 188, 2009.

12. Portugal. Decreto-Lei $n^{\circ} 80 / 2006$ de 4 de Abril. Estabelece a Norma Técnica NTSCE02-Metodologia para auditorias periódicas de qualidade do ar interior em edifícios existentes no âmbito do RSECE. Diario da Republica . 4 abr 2006.

13. Carvalho R, Coelho D, Ferreira C, Nunes T. A Monitorização da qualidade do ar interior (QAI) em Portugal - Estudo comparativo de metodologias de amostragem e medição de QAl. Aveiro: Universidade de Aveiro; 2009.
14. Obesidade online (webpage on the Internet). Lisboa: obesidade online. [cited $2011 \mathrm{Jul}$ 5]. Available from www.obesidade.online.pt

15. Shusterman D, Murphy MA. Nasal hyperreactivity in allergic and non-allergic rhinitis: a potential risk factor for non-specific building-related illness. Indoor Air. 2007;17(4):328-33. http://dx.doi. org/10.1111/j.1600-0668.2007.00482.x

16. Almeida SM, Canha N, Silva A, Freitas MC, Pegas P, Alves $\mathrm{C}$, et al. Children exposure to atmospheric particles in indoor of Lisbon primary schools. Atmos Environ. 2011;45(40);7594-9.

17. Pegas PN. Indoor air quality in elementary schools of Lisbon and Aveiro [thesis]. Aveiro: Universidade de Aveiro; 2012.

18. van Dijken F, van Bronswijk JE, Sundell J. Indoor environment and pupils' health in primary schools. Build Res Inform. 2006;34(5):437-46.

19. Borodinecs A, Budjko Z. Indoor air quality in nursery schools in Latvia. Proceedings of the 9th International At Exhibition Healthy Buildings; 2009 Sep 13-17; Syracuse, USA.

20. Mumovic D, Palmer J, Davies M, Orme M, Ridley I, Oreszczyn T, et al. Winter indoor air quality, thermal comfort and acoustic performance of newly built secondary schools in England. Build Environ. 2009;44(7):1466-77.

21. Al-Rashidi K, Loveday D, Al-Mutawa N. Impact of ventilation modes on carbon dioxide concentration levels in Kuwait classrooms. Energy Build. 2012;47:540-9.

22. Saijo Y, Kishi R, Sata F, Katakura Y, Urashima Y, Hatkeyama A, et al. Symptoms in relation to chemicals and dampness in newly built dwellings. Int Arch Occup Environ Health. 2004;77(7):461-70.

23. Armstrong BC, White E, Saracci R. Principles of exposure measurement in Epidemiology. Oxford: Oxford University Press; 1994.

24. Fernandes E0, Silva GV, Martins A, Samúdio MJ, Guedes J, Barros H, et al. Saúde ambiental em ambiente escolar. In: Borrego C, Carvalho A, Miranda Al, Costa AM, Monteiro A., Amorim JH, et al, editors. Investigação em ambiente e saúde, desafios e estratégias. Aveiro: Universidade de Aveiro/CESAM; 2009. p. 83-7.

25. Horak E, Morass B, Ulmer H. Association between environmental tobacco smoke exposure and wheezing disorders in Austrian preschool children. Swiss Med Wkly. 2007;137(43-44):608-13.

26. Kabir Z, Manning PJ, Holohan J, Keogan S, Goodman PG, Clancy L. Second hand smoke exposure in cars and respiratory health effects in children. Eur Respir J. 2009; 34(3):629-33.

27. Bernstein JA, Alexis N, Bacchus H, Bernstein IL, Fritz P, Horner $\mathrm{E}$, et al. The health effects of non-industrial indoor air pollution. J Allergy Clin Immunol. 2008;121(3):58591. PMid:17990155

28. Moraes AP. Qualidade do ar interno com ênfase na concentração de aerodispersóides nos edifícios [dissertation]. São Paulo: Universidade de São Paulo; 2006. 


\section{Sobre os autores}

Ana Maria da Conceição Ferreira

President. Scientific Committee, Environmental Health Course, Coimbra School of Health Technology, Coimbra, Portugal.

\section{Massano Cardoso}

Full Professor. University of Coimbra School of Medicine, Coimbra, Portugal. 